\title{
Exploring Responsiveness in the U.S. House of Representatives
}

\author{
Philip D. Waggoner \\ College of William and Mary \\ pdwaggoner@wm.edu
}

\begin{abstract}
Legislators are elected to be the voice of their constituents in government. Implicit in this electoral connection is the responsiveness of legislators to the preferences of constituents. Many past approaches only examine successful legislative behavior blessed by the majority party, not all legislative behavior, thereby limiting inference generalizability. I seek to overcome this limitation by considering bill sponsorship as an outlet in which all members are free to engage. Testing expectations on bill sponsorship in the 109th and 110th Congresses, I find that legislators are mostly responsive to constituents' ideological preferences, though only on safely-owned policy issues. I compare these findings to roll call voting on the same issues in the same Congresses and find a different pattern, suggesting legislators leverage bill sponsorship differently than roll call voting as they signal policy priorities. ${ }^{1}$
\end{abstract}

\section{Introduction}

Legislators are elected to represent their constituents. While they exist and operate within their districts and the chamber, the pull of their constituents is ubiquitous. Yet, to what degree are constituencies actually impacting their legislators' behavior in office? In studies of responsiveness, this question centers on the degree to which constituent preferences impact actions of their elected officials. In turn, how adequately are legislators representing their districts with their limited time and resources in office? This latter question is a consequential component of understanding the quality of representation and the responsiveness of elites. Yet, the findings on the degree of responsiveness of legislators to constituents has been mixed. Some have found responsiveness at the national (Page et al. 1984; Shapiro 2011; Stimson, MacKuen, and Erikson 1995), state (Lax and Phillips 2009a), and even city levels of government (Tausanovitch and Warshaw 2013). Others, though, are less sanguine about elite responsiveness, contending that it is quite elusive. Legislators may not be as representative of and responsive to constituents as some consider (Bafumi and Herron 2010; Fowler and Hall 2016). And still others find evidence responsiveness, but in conditional, limited, and indirect contexts (Clinton 2006; Lax and Phillips 2012; Waggoner 2018).

There remains a paradox in the literature: are legislators responsive to constituent preferences, or are they not? In this paper, I address this question by evaluating a less commonly assessed realm of legislative behavior: bill sponsorship. I contend that bill sponsorship affords an alternative look at legislative responsiveness, by providing a window into the policy priorities of all legislators, such that generalizable inferences can be made about the responsiveness of

${ }^{1}$ I thank Robert Y. Shapiro for reviewing several iterations of this project, and for providing invaluable feedback along the way. I am also indebted to Justin Kirkland and Kent Tedin for their many helpful comments. All mistakes remain my own. 
legislators.2 Inversely, by looking to legislative outcomes, the sample may be biased in that only successful legislative behavior is considered. Taken with the vast amount of power wielded by the majority party in determining the legislation that gets a vote, and therefore the legislation that emerges from the chamber (Cox and McCubbins 2005; Finocchiaro and Rohde 2008), past studies in this vein, then, have essentially observed majority party responsiveness.

I proceed by reviewing the relevant literature and then present the context of representation and issue-specific responsiveness, informing expectations of constituents' ideological impact on bill sponsorship. I then test the expectations using the Tausanovitch and Warshaw (2013) multilevel regression with poststratification mean estimates of district-level constituent ideology to predict the types of bills introduced by legislators in the $109^{\text {th }}$ and $110^{\text {th }}$ U.S. House of Representatives. I find that legislators are mostly responsive to constituent ideological preferences, though only on select issues owned by their respective parties. Then, I follow the analysis with an exploration of roll call voting on the same issues to assess whether roll call voting and sponsorship reveal distinct variance in responsiveness. I find a different pattern where responsiveness to constituent preferences is consistent, without regard for the safety of the issue. This supports the central premise that bill sponsorship provides a distinct look at whether or not, as well as the degree to which legislators are responsive to the preferences of constituents.

\section{Constituent Preferences and Representation}

Legislators are elected to represent constituents by being their voice in government. There is a rich tradition of literature underlying this representative relationship (e.g., Achen 1978; Cameron, Epstein, and O'Halloran 1996; Griffin and Flavin 2011; Grimmer 2013b; Miller and Stokes 1963). Variation in behavior of elites (Gerber 1996; Gilens 2005) and the mass public (Erikson, Mackuen, and Stimson 2002; Page and Shapiro 1992) are useful in informing a better understanding of the degree to which legislators and legislative institutions are responsive to constituents, despite limited time and resources in office.

Specifically, legislators strategically cast their time in office to different constituencies at different times (Grimmer 2013a). Also, different constituencies prize different forms of representation as a function of unique individual-level attributes, from descriptive representation to policy representation (Eulau and Karps 1977; Griffin and Flavin 2011; Harden 2013, 2016).

Away from their districts while in Washington, though, legislators are confronted with different and divergent cross pressures (Carey 2007). Whether interest groups, party leaders, or their own devotion to the party in the chamber, legislators must balance these cross pressures as they engage with the policy process, all the while, remaining accountable to constituents.

Studies of mass-elite linkages provide insight into how elites impact constituents with their time spent in office (Levendusky 2010) as well as how constituents impact elites' policy

2 The benefits of observing sponsorship over other forms of behavior as discussed here and elsewhere by no means imply that sponsorship is the only place where responsiveness can be observed, or even that it is the ideal place to observe responsiveness. Rather, I suggest that sponsorship affords a fresh take on the responsiveness question aiding in the uncovering of greater nuance in responsiveness and legislative institutional behavior more broadly. I address this at greater length below. 
output (Peress 2013). Indeed, studies have evaluated the degree to which legislators pay attention to subconstituencies (Bishin 2009) as well as how and when legislators engage with their constituents in a strategic manner (Grimmer 2013a, 2013b; Grose, Malhotra and Van Houweling 2015).

But establishing mass-elite linkage merely begins the story. The crux of representational quality lies in the degrees to which legislators respond to the preferences of constituents. Many rely on roll call voting, yet find mixed results regarding responsiveness, with some finding broad responsiveness (Bianco 1994; Cayton 2016; Page et al. 1984) and others finding conditional evidence of responsiveness (Clinton 2006). ${ }^{3}$

Another common approach in studying responsiveness is assessing policy outcomes. These findings on the connection between constituent preferences and legislative behavior have also been mixed. While some have found a high degree of responsiveness at various levels of government (Erikson, Wright, and McIver 1993; Stimson, MacKuen, and Erikson 1995; Tausanovitch and Warshaw 2013), others have found little to no evidence of alignment between elites and constituents, suggesting that representatives are more extreme than their constituents (Bafumi and Herron 2010). Thus, the extent to which legislators' behavior is responsive to and corresponds with constituents remains unresolved.

\section{Bill Sponsorship as Issue-Specific Responsiveness}

In light of the electoral and representational connections between constituents and legislators, constituents should have some level of impact on the behavior of legislators. Seen through a range of behavior from district casework to time and resources expended on sponsoring bills, legislators have an incentive to be working for their constituents for the sake of winning reelection, crafting good public policy (Fenno 1978), and claiming credit for legislative accomplishments along the way (Mayhew 1974).

If legislators positively respond to this electoral incentive and work for their constituents, then there should be a signature of constituents on their legislative work. An ideal form of legislative work that is a tangible expression of prioritization is a sponsored bill given the benefit, among others, of credit claiming (Mayhew 1974). As legislators are tasked with straddling their districts and the chamber, they must constantly make prioritization decisions, allowing them, in turn, to act as "entrepreneurs" of unique issues and policy agendas (Wawro 2001). They are expected to work for the benefit of their party while also staying in tune with constituents. Therefore, though some bills require more or less work than others, bills remain observable pieces of evidence into the cost calculations and prioritization decisions made by all legislators. And given the thousands of bills introduced in a single legislative session, legislators appear to view bill sponsorship as consequential. In light of the prevalence of sponsorship behavior, coupled with the electoral incentives for legislators to respond to the preferences of their constituents, sponsored bills should be an avenue where responsiveness can be detected.

An additional benefit of looking at bill sponsorship to assess responsiveness is that in light of the strength of the majority party in chamber processes, nothing is considered for a vote or passes without the blessing of the majority party. The locus of responsiveness in roll call

3 See Shapiro (2011) for a thorough review of democratic responsiveness. 
voting behavior and in successfully passed legislation, then, reflects the priorities of the majority party to a large degree, rather than the priorities of all members of chamber. Successfully passed legislation and roll call voting are only subsamples of legislation under consideration, such that the impact of constituent preferences on majority party responsiveness is being observed in these cases. As such, numerous other outlets such as bill sponsorship and committee work offer legislators opportunities to highlight their intensity of specific policy positions that reach beyond casting a roll call vote (Hall and Wayman 1990). Bill sponsorship, specifically, is an active outlet of legislative behavior open to all legislators providing the opportunity to introduce a bill on any topic during the course of a single legislative session (Wawro 2001). While bill sponsorship is valuable to address the responsiveness of legislators to their constituents' preferences, past approaches analyzing bill sponsorship have often focused on agenda setting (Schiller 1995; Burstein, Bauldry, and Froese 2005; Rocca and Gordon 2010; Woon 2008), or on sub-group behavior in the legislative process (Barnello and Bratton 2007; Rocca and Sanchez 2008; Whitby 2002; Wilson 2010). And at the state level, Gamm and Kousser (2010) leveraged bill sponsorship to explore variance in district homogeneity as it relates to the targeted versus broad nature of bills.

Importantly, I am not suggesting that bill sponsorship is the only, or even the primary way legislators signal responsiveness to constituents. Roll call voting as discussed above, legislative particularism (Ashworth and Bueno de Mesquita 2006), and constituent casework (Harden 2013) are all cases of responsiveness. For example, more moderate legislators representing more moderate constituencies may be less apt to respond to constituent preferences through targeted policy responsiveness (e.g., Gamm and Kousser 2010). Whether this is the case or not, is beyond the scope of this analysis. For present purposes, the benefit of leveraging bill sponsorship in studying responsiveness is offering a different view of responsiveness based on a form of behavior that considers all legislators engaging in the same process at the same time. Thus, my analysis is intended to add nuance to the thriving responsiveness literature, not supplant previous findings.

\section{The Link: Issue Ownership}

While there is room to expect constituent impact on legislative behavior, the linkage between constituents and specific issues must also be established. I suggest issue ownership provides a foundation to link issue-specific preferences to elite responsiveness. Building on the demonstrated pattern of ideological sorting into partisan camps (Levendusky 2009), today on average, conservatives are Republicans and liberals are Democrats, suggesting a high degree of correlation between party identification and ideology. Indeed, using American National Election Study (ANES) data, Abramowitz and Saunders (2008) show that the correlation between party identification and ideology in the mass public has been rapidly increasing since 1972 , with polarization between the parties extending even to positions on specific issues (546-47). This paves the way for expectations on a connection between ideological preferences and party-owned issues. Constituents' ideological preferences on issues aligning with their respective parties should act as signals to legislators on the types of bills they should sponsor. For example, conservatives typically favor increased defense spending and capabilities, suggesting 
that conservative ideology should positively predict the sponsoring of defense-related legislation. But how do parties come to "own" issues?4 Egan (2013) notes that partisan issue ownership flows from the fact that parties prioritize certain issues over others and are in turn awarded ownership on certain issues by the mass public. Others, too, have echoed this notion that stances on certain issues should vary by parties based on highlighting of certain issues to the exclusion of others, such as Petrocik's (1996) findings, summed up by Hetherington and Rudolph $(2015,139)$ : "Republicans tend to talk about foreign policy because they "own" it while Democrats tend to talk about social welfare policy because they "own" it." Therefore, Republican-owned issues should be conservative-owned issues, while Democratic-owned issues should be liberal-owned issues, to the extent that we should expect to see constituents influencing legislative behavior. ${ }^{5}$

While linking ideology and partisanship in this study, it is important to note that I am not conflating these concepts. Indeed, party is different than ideology in that the former is measurable and observable both for legislators as well as the public, while the latter is unobservable requiring estimation based on other forms of behavior (e.g., roll call voting (Clinton 2006)). Rather, I am suggesting that given the high correlation between party and ideology both in the public (Abramowitz and Saunders 2008) as well as among legislators (Poole and Rosenthal 1997), constituent ideology should impact issue-specific legislative behavior most powerfully for partisan owned issues.

And beyond expected partisan and ideological variance, demographically-unique constituencies should reveal valuable information about the legislative behavior we should expect to see (Adler and Lapinksi 1997; Fowler and Hall 2016), such that issue-specific behavior should comport with unique district compositions. In short, constituencies should

${ }^{4}$ While there is room to expect constituent impact on legislative behavior, the linkage between constituents and specific issues must also be established. I suggest issue ownership provides a foundation to link issue-specific preferences to elite responsiveness. Building on the demonstrated pattern of ideological sorting into partisan camps (Levendusky 2009), today on average, conservatives are Republicans and liberals are Democrats, suggesting a high degree of correlation between party identification and ideology. Indeed, using American National Election Study (ANES) data, Abramowitz and Saunders (2008) show that the correlation between party identification and ideology in the mass public has been rapidly increasing since 1972, with polarization between the parties extending even to positions on specific issues (546-47). This paves the way for expectations on a connection between ideological preferences and party-owned issues. Constituents' ideological preferences on issues aligning with their respective parties should act as signals to legislators on the types of bills they should sponsor. For example, conservatives typically favor increased defense spending and capabilities, suggesting that conservative ideology should positively predict the sponsoring of defense-related legislation. But how do parties come to "own" issues? Egan (2013) notes that partisan issue ownership flows from the fact that parties prioritize certain issues over others and are in turn awarded ownership on certain issues by the mass public. Others, too, have echoed this notion that stances on certain issues should vary by parties based on highlighting of certain issues to the exclusion of others, such as Petrocik's (1996) findings, summed up by Hetherington and Rudolph (2015, 139): "Republicans tend to talk about foreign policy because they "own" it while Democrats tend to talk about social welfare policy because they "own" it." Therefore, Republican-owned issues should be conservative-owned issues, while Democratic-owned issues should be liberal-owned issues, to the extent that we should expect to see constituents influencing legislative behavior.

5 This approach by no means provides a perfect linking of ideological directions to issues. Yet, it does provide a baseline allowing for exploration of ideological preferences and issue-specific responsiveness. 
have some level of influence on their elected officials, and this influence should be observable along partisan and ideological lines.

\section{Issues and Expectations}

Given the expectation that constituents varying along an ideological dimension should influence their legislators' behavior on issue-specific bill sponsorship, I use recent and major polling data to connect ideologies and parties to specific issues. This is a necessary step to generate testable hypotheses.

The first broad policy issue considered is defense. This is categorized as a "conservative" issue, based on the findings from Gallup that more Republicans (56\%) think that defense spending is too little, compared with Independents (33\%) and Democrats (17\%) as of 2015 (McCarthy 2015). Selection of this issue as "conservative" is also supported by Egan's $(2013,67)$ categorization, finding ownership of defense by Republicans spanning four decades. Therefore, conservative constituencies should increase the likelihood of defense-related bills being introduced.

The second policy issue area is the economy. ${ }^{6}$ While the economy is a pronounced partisan issue, especially in poor economic times (Hetherington and Rudolph 2015), Gallup finds stronger ties between conservatives and Republicans on the economy than for liberals and Democrats on the economy (Jones 2016). While Democrats are less liberal on the economy than on social issues, the trend tying party to ideology on the economy remains more pronounced among Republicans than Democrats. Therefore, the economy is considered a conservative issue, with more conservative constituencies increasing the likelihood of economyrelated bills being introduced.

The third issue area is agriculture. Republicans view farming and agriculture more positively than Democrats by a margin of 9 points (Newport 2013). Further, ideological differences even extend to how conservatives and liberals view rural and urban areas. The vast majority of "consistent conservative" respondents said they would rather live in a rural area (41\%) or small town (35\%), compared to $46 \%$ of "consistent liberals" who would choose to live in a city, and $21 \%$ in the suburbs, while only $11 \%$ would pick a rural area and $20 \%$ would pick a small town (Pew 2014). Given these differences between the parties as well as ideological positions, conservative constituencies should increase the likelihood of legislators introducing agriculturerelated bills.

I shift now to traditionally liberal policy issues. The fourth broad policy area is education. Based on the findings from an Education Next poll, covered by the Brookings Institution, while there is some agreement between the parties on various aspects of education reform, the major disparity between the two parties is on thoughts toward increases in spending on public schools. Nearly $75 \%$ of Democrats favor increased public school spending, compared

\footnotetext{
6 Though the economy could be considered a non-partisan issue to the extent that the public rewards the incumbent party if the economy is good, and penalizes the incumbent party if the economy is performing poorly (e.g., Kiewiet and Udell 1998), Bafumi and Shapiro $(2009,11)$ highlight the relative stability of cleavages between the parties as well as ideologies on economic issues over time.
} 
to $54 \%$ of Republicans opposing it (Henderson, Peterson, and West 2014; Henderson 2015). Thus, liberal constituencies should increase the likelihood of introducing education bills.

The fifth issue area is healthcare. This is considered a liberal issue because traditionally, and especially exacerbated by the years-long debate over the Affordable Care Act, liberals tend to favor universal health coverage and a more pronounced role for the government in this regard (Aaron and Lucida 2013). And similar to defense above, Egan (2013) finds healthcare is another consistently owned issue by Democrats. Therefore, liberal constituencies should increase the likelihood of legislators introducing healthcare-related legislation.

The sixth and final issue area considered is civil liberties and rights. Though these trends vary when th ${ }^{7}$ e threat of terrorism is high, liberals are less willing to trade off civil liberties than conservatives (Davis and Silver 2004). This finding is coupled with the historical trend of many prominent civil liberties and rights advocacy groups being ideologically liberal (e.g., ACLU, AFL-CIO, etc.). Therefore, liberal constituencies should increase the likelihood of introduced civil liberties and civil rights bills.

For ease of interpretation, I generate the following testable hypotheses in terms of conservative constituencies (e.g., For conservative issues, conservative constituencies should increase likelihood of sponsored bills on $\mathrm{X}$; for liberal issues, conservative constituencies should decrease the likelihood of sponsored bills on Z).

\section{Conservative Issues Hypotheses}

$\mathrm{C}_{1}$ : Conservative constituencies increase likelihood of introduced defense bills.

$\mathrm{C}_{2}$ : Conservative constituencies increase likelihood of introduced economy bills.

$\mathrm{C}_{3}$ : Conservative constituencies increase likelihood of introduced agriculture bills.

\section{Liberal Issues Hypotheses}

$\mathrm{L}_{1}$ : Conservative constituencies decrease likelihood of introduced education bills. $\mathrm{L}_{2}$ : Conservative constituencies decrease likelihood of introduced healthcare bills. $\mathrm{L}_{3}$ : Conservative constituencies decrease likelihood of introduced civil liberties bills.

\section{Methods and Data}

The goal in this analysis is to test the degree of ideological responsiveness to constituent preferences through bill sponsorship. I seek to estimate the likelihood that constituent ideological preferences on broad policy issues impact legislators' bill sponsorship decisions. In order to do this, I begin by specifying my dependent variables of interest, which are dichotomous bill topics for each of the six key issues: Defense, Economy, Agriculture, Education, Healthcare, and Civil Liberties/Civil Rights. The individual bill is the unit of

\footnotetext{
7 All of these issues are also party-owned issues based on Egan's $(2013,67)$ classification, with issues 1-3 being Republican issues and issues 4-6 being Democratic issues.
} 
analysis. The counts of bills introduced for each issue are displayed in Table $1 .{ }^{8}$ Using the Congressional Bills data from Adler and Wilkerson (2012), I analyze sponsored bills in the 109 th and $110^{\text {th }}$ Congresses, which covered a four year period from January 3 , 2005 to January 3, 2009, with the topics coded according to the Policy Agendas Project (Baumgartner and Jones 1993).?

My main independent

\begin{tabular}{|l|l|}
\hline \multicolumn{2}{|l|}{ Table 1: Bill Totals by Issue, 109th $110^{\text {th }}$ Congress } \\
\hline Policy Issue & Count \\
\hline Defense & 970 \\
\hline Economy & 543 \\
\hline Agriculture & 260 \\
\hline Education & 706 \\
\hline Healthcare & 1596 \\
\hline Civil Liberties \& Rights & 207 \\
\hline
\end{tabular}
variable used to predict the likelihood of issue-specific bill sponsorship is constituent ideology. This predictor is the multilevel regression with poststratification (MRP) mean estimates from Tausanovitch and Warshaw (2013). It captures constituent "ideology" as a weighted average of citizen responses to several waves of the National Annenberg Election Survey (NAES) and the Cooperative Congressional Election Study (CCES) from 2000 to 2010 as a function of demographic and geographic characteristics, and poststratified based on actual state populations. Estimates are generated for every U.S. Congressional district, and place constituents on a single leftright dimension, similar to other measures of ideology (e.g., Poole and Rosenthal 1997), where negative values indicate increased liberalness and positive values indicate increased

Figure 1: Correlation between Constituent and Legislator Ideology

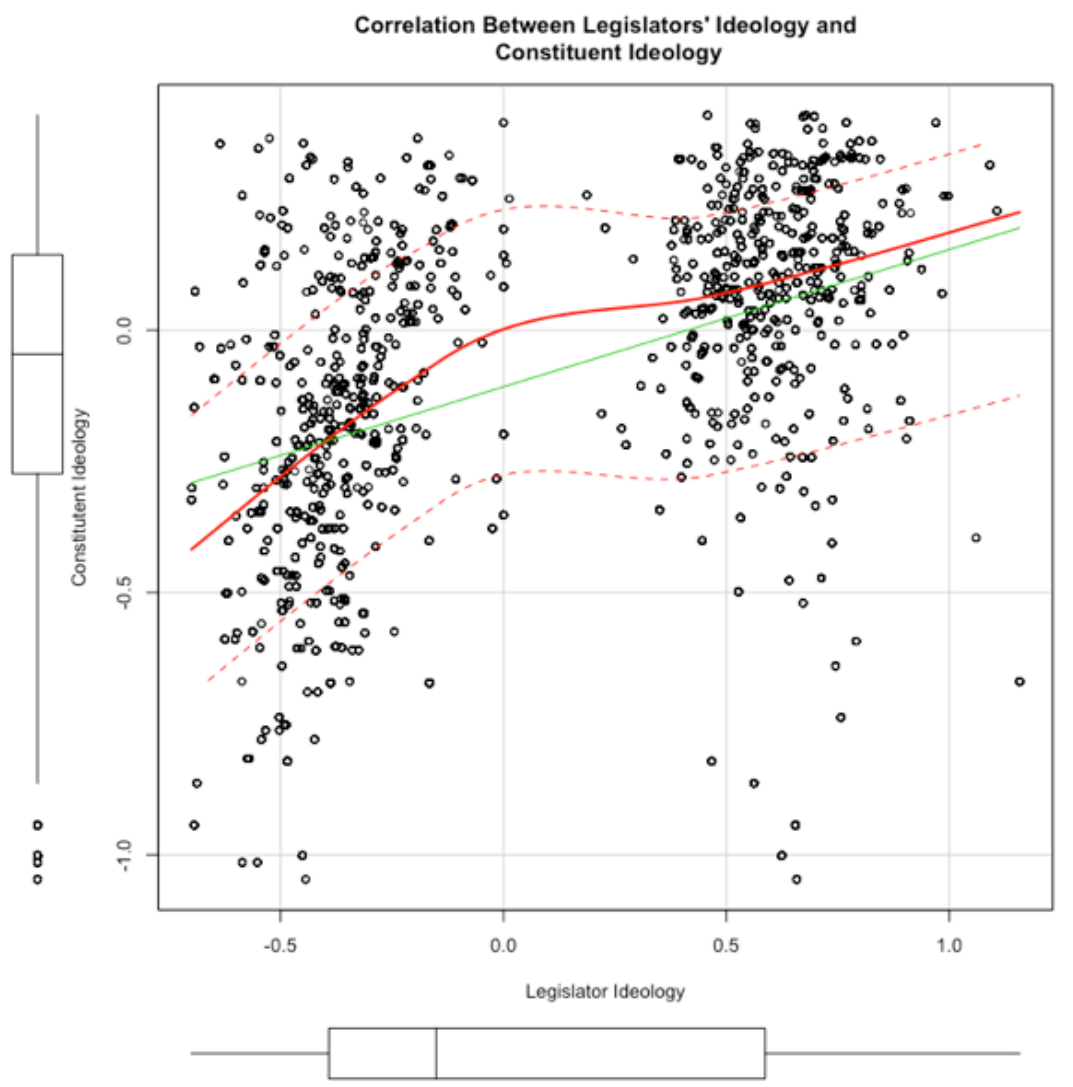

8 There were 13,097 bills introduced in the $10^{\text {th }}$ and $110^{\text {th }}$ Congresses. The bill totals in Table 1 do not add up to 13,097 , because there were many other bills beyond these six issues of interest introduced in these Congresses.

9 These Congresses were selected, because the MRP estimates of constituent ideology align with this time period. 
conservativeness. 10 In light my assumption that the ideology of constituents captures similar information as the ideology of legislators with liberals on the left and conservatives on the right, consider Figure 1 below. Figure 1 shows the correlation between legislators' ideology, using DWNOMINATE ideal points (Poole and Rosenthal 1997), and the Tausanovitch and Warshaw (2013) mean MRP estimates of constituent ideology.

I control for a vector of theoretically relevant covariates that have been found to impact Congressional behavior, including legislators' political parties and their ideologies measured using the DW-NOMINATE scores given the impact of party and ideology on behavior (Lawrence, Maltzman and Smith 2006). ${ }^{11} \mathrm{I}$ also control for majority party status, which is a dichotomous indicator, given the gatekeeping policy power retained by the majority party (Cox and McCubbins 2005). Additional controls include a legislator's seniority, which is continuous, given the effects of seniority on success (Anderson, Box-Steffensmeier and Sinclair-Chapman 2003), and also a legislator's ability to move legislation through the process, measured using Volden and Wiseman's (2014) legislative effectiveness scores. The quality of a legislator, captured in this measure, could certainly influence their propensity to sponsor legislation. Given the influence of "bill managers" on legislators' options for moving bills through and out of committees (Evans 1991; Hall and Evans 1990), I include two key controls for whether a legislator was a member of a powerful committee (rules, ways and means, or appropriations) and also, whether a legislator was a subcommittee chair, given that these are the workhorses of policy in the chamber. ${ }^{12}$ And finally, given the influence of district characteristics on legislative behavior (Waggoner 2018), I adopt Fowler and Hall's (2016) strategy for accounting for issue specific district characteristics using census data, including, percent in district as military personnel (defense model), percent in district in poverty (economy model), percent in district as farm workers (agriculture model), percent in district as education workers (education model), percent of the population over 64 years old (health model), and finally percent of the district that is African American (civil rights/liberties model). 13

In light of the dichotomous variables of bill topics (e.g., Defense bill=1; Non-Defense Bill=0), I estimate six separate multilevel logistic regressions, each with the dependent variable corresponding to a specific issue, with random effects specified for individual legislators, nested

10 For a detailing of the MRP procedure broadly, see Lax and Phillips (2009b, 109-112). And for additional detailing of the MRP mean estimates of constituent ideology utilized in this paper, see Tausanovitch and Warshaw (2013, 331-335).

11 After checking the variance inflation factor for each covariate in the model, multicollinearity was ruled out as a threat. See these values in the Appendix in Table A1.

12 I control for these major House committee in light of the potential for some legislators' bill sponsorship activity being moderated by the committees on which they serve, such as a rules committee member being required to carry a bill marked up in the House Rules Committee and subsequently reintroduced by that committee as a new bill.

13 I thank an anonymous reviewer for pointing out the need to control for district characteristics. 
within individual districts, within individual states, within individual Congresses. ${ }^{14}$ Upon estimating the models, I generate and plot out of sample predicted probabilities using postestimation simulations, holding all control variables at their mean levels, and present them in Figures 2 and 3 below.

\section{Results and Discussion}

The expected impact of constituent ideology on bill sponsorship, given that constituent ideology is measured such that positive values are more conservative and negative values are more liberal, should be positive for conservative issues and negative for liberal issues. As such, the goal of this analysis is to take a step in understanding whether the ideological preferences of constituents have any measurable impact on the policy focus of legislators. See the full model results from each specification in Table 2 below.

At first glance, note the top row of coefficients in Table 2 capturing the impact of constituent ideology on the likelihood of legislators sponsoring specific bill topics. In all six models the coefficients are pointing in the hypothesized direction of positive for conservative issues and negative for liberal issues.

Importantly, though, the responsiveness of legislators is not consistent across all issues. In four of the six models - Defense, Agriculture, Healthcare and Civil Liberties and Rights there is a statistically significant impact in predictive power at $\mathrm{p}<.05$. Though addressed in greater depth below, the variance across issues could mean that the parties do not have clearly staked-out ownership of the economy or education at least in their bill sponsorship, or it could be due to a lack of directional assessment in the policy proposal. In line with expectations, though, conservative constituencies influence the bill sponsorship activity of their legislators by encouraging the sponsorship of bills on two major issues that traditionally align with conservative ideology: Defense and Agriculture. The same trend is true for liberal constituencies for two commonly liberal issues: Healthcare and Civil Rights, with Education being just shy of the tradition level of significance.

\footnotetext{
${ }^{14}$ I opt for the binary modeling approach over an event count approach, because the goal is to determine that which influences the likelihood of sponsoring any bill related to the issue of interest. This is in contrast with the event count approach which taps prioritization of a given issue (i.e., more or less sponsorship and thus focus on a certain issue). While other valuable studies have leveraged the event count approach (e.g., Woon 2009), the scope of the question in this analysis is slightly different. Still, additional negative binomial count models are estimated and included in the Appendix, and mostly support the main findings in Table 2.
} 
American Review of Politics

Volume 36, Issue 2

\begin{tabular}{|c|c|c|c|c|c|c|}
\hline & $\begin{array}{l}\text { Dependent } \\
\text { variable: }\end{array}$ & & & & & \\
\hline & $\begin{array}{l}\text { Sponsored Bill } \\
(0 / 1)\end{array}$ & & & & & \\
\hline & Defense & Economy & Agriculture & Education & Health & $\begin{array}{l}\text { Civil Liberties/ } \\
\text { Rights }\end{array}$ \\
\hline & (1) & (2) & (3) & $(4)$ & (5) & $(6)$ \\
\hline \multirow[t]{2}{*}{ Constituent Ideology } & $0.705^{* * *}$ & 0.226 & $0.913^{* *}$ & $-0.392^{*}$ & $-0.457^{\cdots *}$ & $-0.968^{\cdots *}$ \\
\hline & $(0.189)$ & $(0.250)$ & $(0.381)$ & $(0.202)$ & $(0.153)$ & $(0.357)$ \\
\hline \multirow[t]{2}{*}{ Legislator Ideology } & 0.086 & 0.124 & $-0.347^{*}$ & -0.079 & -0.055 & -0.064 \\
\hline & $(0.101)$ & $(0.126)$ & $(0.192)$ & $(0.116)$ & $(0.080)$ & $(0.197)$ \\
\hline \multirow[t]{2}{*}{ Majority Party } & $-0.154^{*}$ & -0.127 & 0.141 & -0.124 & $0.277^{* *}$ & -0.131 \\
\hline & $(0.084)$ & $(0.109)$ & $(0.160)$ & $(0.097)$ & $(0.068)$ & $(0.177)$ \\
\hline \multirow[t]{2}{*}{ Seniority } & $-0.019^{*}$ & $-0.047^{\cdots}$ & 0.006 & $-0.033^{* * *}$ & $0.031^{* * *}$ & 0.027 \\
\hline & $(0.011)$ & $(0.015)$ & $(0.020)$ & $(0.012)$ & $(0.008)$ & $(0.019)$ \\
\hline \multirow[t]{2}{*}{ Legislative Effectiveness } & 0.035 & $0.054^{*}$ & -0.016 & 0.007 & $-0.108^{\cdots *}$ & -0.045 \\
\hline & $(0.022)$ & $(0.028)$ & $(0.047)$ & $(0.025)$ & $(0.020)$ & $(0.042)$ \\
\hline \multirow[t]{2}{*}{ Power Committee } & $-0.174^{*}$ & $0.768^{\cdots *}$ & $0.328^{*}$ & $-0.237^{* *}$ & -0.023 & $-0.497^{\cdots *}$ \\
\hline & $(0.089)$ & $(0.105)$ & $(0.153)$ & $(0.102)$ & $(0.069)$ & $(0.189)$ \\
\hline \multirow[t]{2}{*}{ Subcommittee Chair } & -0.117 & -0.187 & 0.039 & -0.092 & -0.049 & 0.065 \\
\hline & $(0.097)$ & $(0.131)$ & $(0.175)$ & $(0.112)$ & $(0.075)$ & $(0.194)$ \\
\hline \multirow[t]{2}{*}{ Party } & $-0.004^{* *}$ & 0.002 & -0.002 & -0.001 & -0.0003 & 0.003 \\
\hline & $(0.001)$ & $(0.002)$ & $(0.002)$ & $(0.001)$ & $(0.001)$ & $(0.002)$ \\
\hline \multirow[t]{2}{*}{ \% Military Personnel } & $18.141^{\cdots *}$ & & & & & \\
\hline & $(2.511)$ & & & & & \\
\hline \multirow[t]{2}{*}{$\%$ in Poverty } & & $-2.096^{*}$ & & & & \\
\hline & & $(1.098)$ & & & & \\
\hline \multirow[t]{2}{*}{ \% Farm Workers } & & & $20.758^{* * *}$ & & & \\
\hline & & & $(2.661)$ & & & \\
\hline \multirow[t]{2}{*}{ \% Education Workers } & & & & 1.854 & & \\
\hline & & & & $(1.630)$ & & \\
\hline \multirow[t]{2}{*}{$\%$ Over 64 Years Old } & & & & & $3.380^{* *}$ & \\
\hline & & & & & $(1.264)$ & \\
\hline \multirow[t]{2}{*}{$\%$ African-American } & & & & & & $1.069^{* *}$ \\
\hline & & & & & & $(0.474)$ \\
\hline \multirow[t]{2}{*}{ Constant } & $-1.799^{* * *}$ & $-3.264^{\cdots}$ & $-4.389^{\cdots \cdots}$ & $-3.108^{* *}$ & $-2.645^{\cdots *}$ & $-4.906^{\cdots *}$ \\
\hline & $(0.218)$ & $(0.325)$ & $(0.390)$ & $(0.433)$ & $(0.256)$ & $(0.432)$ \\
\hline $\mathrm{N}$ & 13,025 & 13,025 & 13,025 & 13,025 & 13,025 & 13,025 \\
\hline Log Likelihood & $-3,345.379$ & $-2,168.887$ & $-1,185.996$ & $-2,679.151$ & $-4,716.543$ & $-1,028.327$ \\
\hline AIC & $6,716.757$ & $4,363.775$ & $2,397.992$ & $5,384.303$ & $9,459.085$ & $2,082.654$ \\
\hline BIC & $6,813.927$ & $4,460.945$ & $2,495.162$ & $5,481.473$ & $9,556.255$ & $2,179.825$ \\
\hline
\end{tabular}


To illustrate that which these findings suggest in real life, of the 25 bills introduced by Rep. Diana DeGette (D-CO) in the 110th Congress, 16 were health-related. As one of the more liberal members in the chamber with an ideology of -0.42 and similar constituent ideology of $-0.52,64 \%$ of Rep. Degette's bill sponsorship activity was devoted health issues. Similarly, Rep. Jerry Moran (R-KS), with an ideology of 0.565 serving a conservative constituency with an ideology of 0.261 , introduced 13 total bills, 4 of which were agriculture-related. Being a Representative from a mostly rural state and conservative district, Rep. Moran dedicated nearly $31 \%$ of his legislative activity to agriculture bills alone, which is the vast majority of his sponsored bills compared to any other issue.

Interestingly, constituent ideology is not a statistically significant predictor of economy and is just shy of significantly predicting sponsorship of education bills. Detecting ownership by the parties of these issues may be complicated by the lack of accounting for the direction of the policy proposal, or it could be that the parties may not be as clearly sorted on education and the economy, at least compared to the other four issues considered above. This could be the case for the economy given the Gallup findings from Jones (2016), where Democrats are less liberal on the economy than they are on social issues. Additionally, regarding education, in the same report from Henderson, Peterson, and West (2014), reported by Henderson (2015), Republicans and Democrats were mostly in agreement on educational reform with little variation among them, with the exception of attitudes toward spending on public education as mentioned above. The result could be a lack of impact on education bill sponsorship. Still, inferences on these two issue areas are impossible to draw based on these findings, due to the lack of ability to distinguish their impacts from zero. Future research should build on these findings by accounting for the ideological direction of the policy proposal to gain a closer look at the intensity and nuance of constituent influence on issue-specific bill sponsorship.

In order to gain a more intuitive look at the findings for the four statistically significant issues in Table 2, consider the plots of predicted probabilities below, segmented by conservative (Figure 2) and liberal (Figure 3) issues. In Figure 2, the predicted probabilities are shown for the likelihood of conservative sponsored bill topics being sponsored across the range of constituent ideology in the dataset, from the most liberal (-1.047) to the most conservative (0.4097). In line with the expectations in $\mathrm{C}_{1}$ and $\mathrm{C}_{3}$, more conservative constituents increase the probability of sponsoring defense and agriculture bills. Note the nearly doubled increase from about $4 \%$ to about $8 \%$, from the most extreme liberal constituency to the most extreme conservative constituency for defense bills, and from nearly no impact to about 3\% for agriculture bills. 


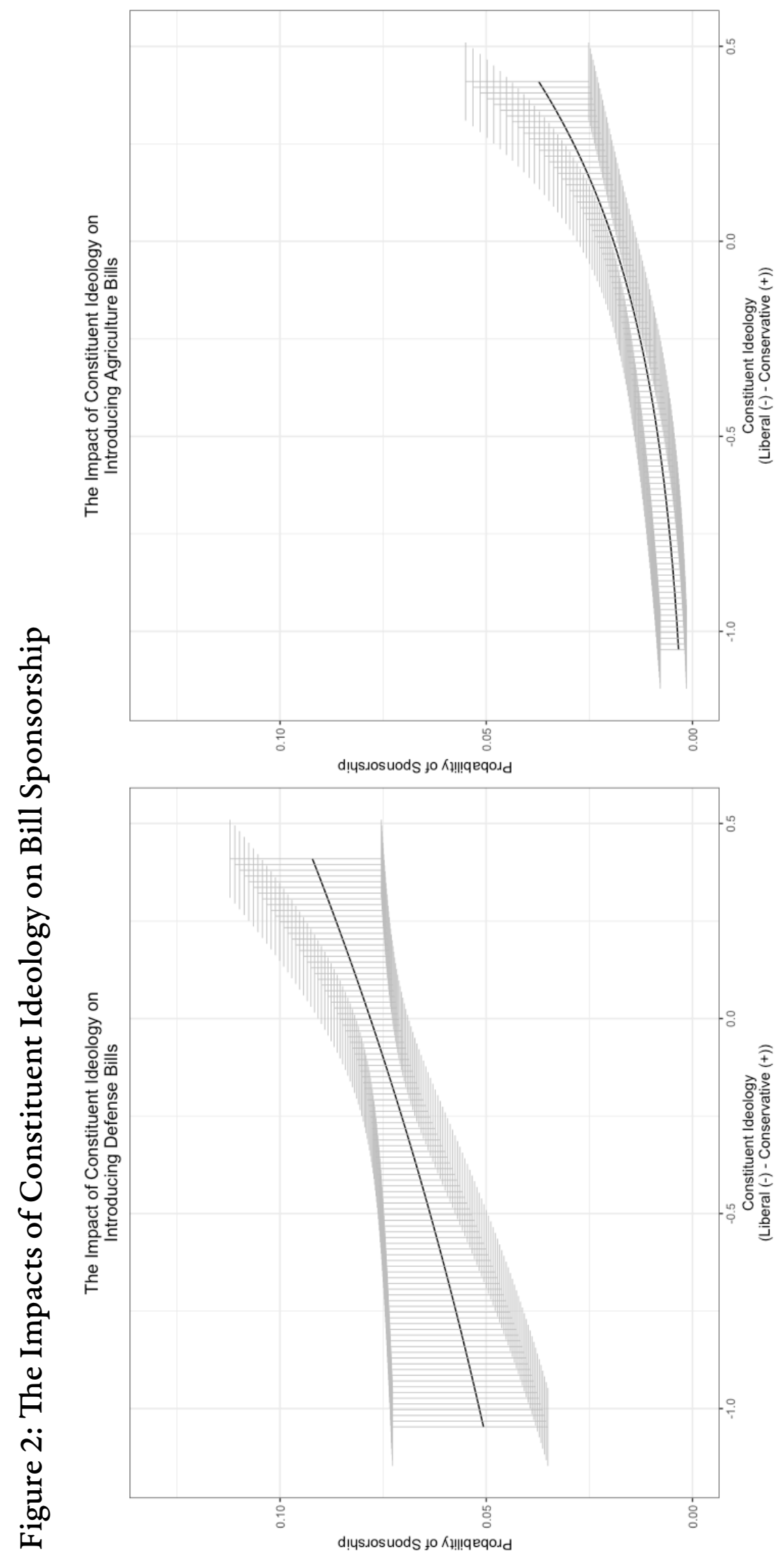




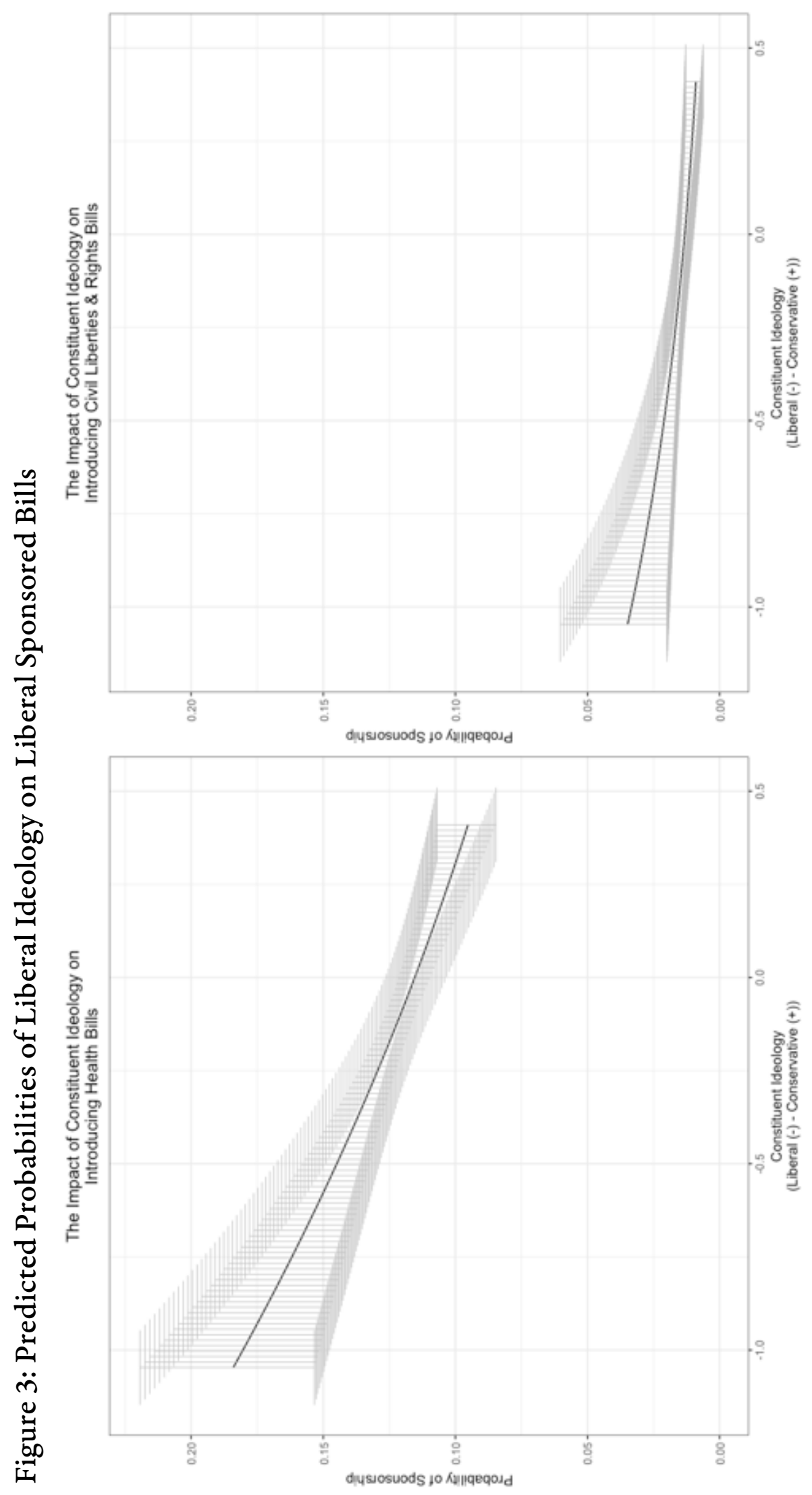


Similarly, Figure 3 shows the likelihood of sponsoring liberal issue bills across the full range of constituent ideology in the dataset. The most pronounced impact of constituent opinion on bill sponsorship topics is for health-related bills, moving from around $18 \%$ for the most liberal constituencies to around $9 \%$ for the most conservative constituencies. The impacts, though moving in the expected direction for civil liberties and civil rights bills in line with $\mathrm{L}_{3}$, is much less pronounced, moving from around $3 \%$ to about $1 \%$, though the relative magnitude of change is still consequential dropping about 2\%. Both panels in Figure 3 strongly support the expectations in $\mathrm{L}_{2}$ and $\mathrm{L}_{3}$.

These findings uncover an additionally interesting point on responsiveness and issue ownership. Some issues are more decidedly "conservative," and others more "liberal." The wide spectrum of magnitudes of effect across the different issues suggest different levels of prominence for some issues compared to others. Healthcare seems to be a key liberal issue, while defense seems to be a key conservative issue, with the predicted probability of sponsoring both of these types of bills doubling when moving from the respective opposite extremes in constituencies. And contrary to what we may expect, a less prominent liberal issue, at least in bill sponsorship, is civil liberties and rights. Ultimately, responsiveness seems to be variable and dependent upon individual issues.

In sum, the results across all multilevel models in Table 2 and the predicted probabilities for the four significant issues including two conservative (Defense and Agriculture), as well as two liberal (Healthcare and Civil Liberties/Rights) issues in Figures 2 and 3, respectively, suggest that constituents' ideological preferences impact their elected officials' behavior. Indeed, bill sponsorship as a form of behavior open to all members in which hundreds of legislators engage is influenced in part by constituents. This points to a broad, albeit variable, pattern of ideological alignment with constituents on safely-owned issues.

\section{Are Bill Sponsorship and Roll Call Voting Different?}

To this point, the findings have provided evidence that legislators respond to the preferences of their constituents to varying degrees on select party-owned issues with the bills they choose to sponsor. Though a step in understanding, I have suggested that bill sponsorship should be an ideal outlet to detect responsiveness to constituents over other approaches, because this form of behavior considers the priorities of all legislators, without regard for legislative success or majority party status, given the wider sample considered, compared to other forms of legislative behavior such as roll call voting. To test this, rather than assume it, I turn now to a series of second stage tests to examine roll call voting behavior on five of the previously examined six partisan-owned issue areas: defense, the economy, agriculture, education and civil liberties/rights.

To gain traction on whether bill sponsorship and roll call voting reveal different patterns in legislators' responses to constituents' preferences, I leverage Fowler and Hall's (2012) conservative vote probability (CVP) as the new dependent variable of interest. The CVP is a nonparametric, parsimonious, and continuous indicator that predicts the rate at which legislators vote more conservatively than the chamber median voter. The CVP is statistically reliable and highly correlated with other summary measures of roll call voting behavior, such as DW-NOMINATE, with member scores calculated across individual issues and individual 
Congresses, ultimately producing directly interpretable output and substantively understandable magnitudes of relatively conservativeness of individual legislators. This is in contrast to more complicated roll call methods (Fowler and Hall 2012). This variable is ideally situated for this analysis, given the ideological component to it. Rather than viewing raw roll call voting values, I am able to link ideological differences in individual voting patterns on the issues of interest to the issue ownership component central to this study. Though relatively new, the CVP measure has been used in recent, major studies of legislative behavior in top political science journals, validating it as a reliable measure of roll call voting (e.g., Alexander, Berry and Howell's 2016 Journal of Politics paper; and Fowler and Hall's 2016 Quarterly Journal of Political Science paper).

As with the prior analysis, my independent variable of interest is the Tausanovitch and Warshaw (2013) mean MRP estimates (Constituent Ideology), which place constituents on a single dimension with negative values indicating increased liberalness and positive values indicating increased conservativeness. Control variables are also similar, including: majority party status, seniority, legislator effectiveness, power committee membership, subcommittee chair, political party, and district characteristics. Given the continuous dependent variable and the pooled data for both Congresses, I estimate a multilevel linear model, with modeled (or , "random") effects for legislators nested within districts, nested within states, and nested within a Congress, for each of the five issues, and display the output in Table 3.

If bill sponsorship and roll call voting are duplicitous expressions of responsiveness, given the dependent variable capturing the likelihood of voting conservative on a bill and the measurement of constituent ideology with positive values indicating increased conservativeness, we should expect to see positive coefficients for constituent ideology only for safely-owned issues (Defense, Agriculture, and Civil Liberties/Rights), and null findings on the other "null" issues from Table 2 above (Economy and Education), in line with the directional logic of issue ownership previously described. The null findings on these issues would indicate that legislators use roll call voting the same way they use bill sponsorship, in that constituents should be exerting the same degree of magnitude on both forms of behavior, such that legislators respond in an ideologically commensurate manner on select issues safely owned by the respective parties. 
American Review of Politics

Volume 36, Issue 2

Table 3: The Effects of Constituent Ideology on Roll Call Voting, 109th - 110th Congress

\begin{tabular}{|c|c|c|c|c|c|}
\hline & $\begin{array}{l}\text { Dependent } \\
\text { variable: }\end{array}$ & & & & \\
\hline & CVP & & & & \\
\hline & Defense & Economy & Agriculture & Education & Welfare \\
\hline & $(1)$ & (2) & (3) & $(4)$ & (5) \\
\hline \multirow[t]{2}{*}{$\begin{array}{l}\text { Constituent } \\
\text { Ideology }\end{array}$} & $0.130^{* * *}$ & $0.145^{* * *}$ & $0.108^{* * *}$ & $0.106^{* * *}$ & $0.114^{* * *}$ \\
\hline & $(0.010)$ & $(0.010)$ & $(0.020)$ & $(0.010)$ & $(0.010)$ \\
\hline \multirow[t]{2}{*}{ Majority Party } & $-0.071^{* * *}$ & 0.00003 & $-0.129^{* * *}$ & $-0.043^{* * *}$ & $-0.017^{* * *}$ \\
\hline & $(0.005)$ & $(0.005)$ & $(0.009)$ & $(0.005)$ & $(0.005)$ \\
\hline \multirow[t]{2}{*}{ Seniority } & $-0.003^{* * *}$ & $-0.003^{* * *}$ & -0.002 & $-0.002^{* * *}$ & $-0.001^{* * *}$ \\
\hline & $(0.001)$ & $(0.001)$ & $(0.001)$ & $(0.001)$ & $(0.001)$ \\
\hline \multirow[t]{2}{*}{$\begin{array}{l}\text { Legislative } \\
\text { Effectiveness }\end{array}$} & $0.003^{*}$ & $0.003^{* *}$ & -0.0004 & $0.003^{* *}$ & 0.002 \\
\hline & $(0.002)$ & $(0.001)$ & $(0.003)$ & $(0.001)$ & $(0.001)$ \\
\hline \multirow[t]{2}{*}{$\begin{array}{l}\text { Power } \\
\text { Committee }\end{array}$} & 0.001 & 0.003 & $-0.024^{* * *}$ & -0.003 & -0.003 \\
\hline & $(0.005)$ & $(0.005)$ & $(0.009)$ & $(0.005)$ & $(0.004)$ \\
\hline \multirow[t]{2}{*}{$\begin{array}{l}\text { Subcommittee } \\
\text { Chair }\end{array}$} & 0.004 & 0.005 & -0.006 & -0.005 & -0.004 \\
\hline & $(0.006)$ & $(0.006)$ & $(0.011)$ & $(0.006)$ & $(0.005)$ \\
\hline \multirow[t]{2}{*}{ Party } & $-0.436^{* * *}$ & $-0.588^{* * *}$ & $-0.480^{* * *}$ & $-0.436^{* * *}$ & $-0.495^{* * *}$ \\
\hline & $(0.005)$ & $(0.005)$ & $(0.010)$ & $(0.005)$ & $(0.005)$ \\
\hline \multirow[t]{2}{*}{$\begin{array}{l}\text { \% Military } \\
\text { Personnel }\end{array}$} & -0.033 & & & & \\
\hline & $(0.170)$ & & & & \\
\hline \multirow[t]{2}{*}{ \% in Poverty } & & 0.047 & & & \\
\hline & & $(0.044)$ & & & \\
\hline \multirow[t]{2}{*}{ \% Farm Workers } & & & $-0.527^{* * *}$ & & \\
\hline & & & $(0.192)$ & & \\
\hline \multirow[t]{2}{*}{$\begin{array}{l}\text { \% Education } \\
\text { Workers }\end{array}$} & & & & 0.051 & \\
\hline & & & & $(0.075)$ & \\
\hline \multirow[t]{2}{*}{$\begin{array}{l}\text { \% African } \\
\text { American }\end{array}$} & & & & & 0.019 \\
\hline & & & & & $(0.015)$ \\
\hline \multirow[t]{2}{*}{ Constant } & $0.304^{*}$ & 0.313 & $0.443^{* * *}$ & $0.263^{*}$ & 0.268 \\
\hline & $(0.183)$ & $(0.242)$ & $(0.116)$ & $(0.147)$ & $(0.195)$ \\
\hline $\mathrm{N}$ & 894 & 894 & 884 & 887 & 894 \\
\hline Log Likelihood & $1,150.583$ & $1,214.497$ & 670.665 & $1,232.810$ & $1,268.534$ \\
\hline AIC & $-2,275.165$ & $-2,402.993$ & $-1,315.330$ & $-2,439.620$ & $-2,511.069$ \\
\hline $\mathrm{BIC}$ & $-2,212.821$ & $-2,340.649$ & $-1,253.132$ & $-2,377.378$ & $-2,448.724$ \\
\hline Note: & \multicolumn{5}{|c|}{${ }^{*} \mathrm{p}<0.1 ;{ }^{* *} \mathrm{p}<0.05 ;{ }^{* * *} \mathrm{p}<0.01$} \\
\hline
\end{tabular}


For parsimony and consistency, I focus discussion on the impact of constituent ideology on roll call voting, which is shown in the first row of coefficients in Table 3. Strikingly, constituent preferences across issues, whether owned or not, positively and significantly influence greater likelihood of voting in line with ideological preferences, even after accounting for district characteristics. Taken with the patterns uncovered in the previous analysis on bill sponsorship, different issues as well as different forms of behavior appear to reflect different patterns and magnitudes of responsiveness, at least as far as ideological alignment is concerned. As such, there is room to suspect legislators use bill sponsorship differently than roll call voting as a means to respond to constituent preferences. Future studies should more closely probe the connection between policy proposals and roll call voting measures. Further, this exercise in both stages of analysis is instructive in that precisely where and how we look for responsiveness can influence whether or not and to what degree we find it.

\section{Conclusion}

In light of the electoral connection between constituents and their legislators, there is a sufficient incentive for legislators to positively respond to the preferences of their constituents. Yet, in addressing whether or not this is actually going on, past approaches have mostly focused on roll call voting or policy output. These and other similar approaches limit the sample of legislators to only those who are successful, which is often the bills that are blessed by the majority party. In this paper I have taken a different approach in assessing legislative responsiveness to constituents, by considering a form of legislative behavior in which all members are free to engage: bill sponsorship. I found compelling evidence that legislators are often responsive to constituents, though to varying degrees. On major policy areas where conservatives and liberals hold clearly-defined positions such that they "own" certain issues, I found that for four of the six major policy issues considered - Defense, Agriculture, Healthcare, and Civil Liberties/Rights - the ideological preferences of constituents impact the likelihood of bills being sponsored on these topics. While past findings have been mixed regarding the degree of legislative responsiveness, this could be due to the form of legislative behavior being considered. The degrees to which they are successful in ensuring passage of these policies is a second order question. Comparing these findings with roll call voting on the same issues for the same Congresses, I found evidence suggesting that bill sponsorship and roll call voting may be distinct expressions of responsiveness. Leveraging issue ownership, the safeness of issues seems to most prominently influence bills sponsorship seems to be a key factor in determining levels of responsiveness through bill sponsorship.

Despite the patterns of variable responsiveness of legislators to their constituents, my findings have a few limitations. Most notably, the clarity of signal from constituents to legislators is a limitation. While constituent ideology appears to predict the likelihood of bill sponsorship for specific issues, the difficulty in establishing causality limits the degree to which I can conclude that constituents are causing legislators to sponsor bills on specific topics. There is indeed congruence between constituents and legislators seen in sponsored bills. Yet, demonstrating causality would require time series methods, such as error correction models aimed at sorting out long-run and short-run causal relationships between sponsorship and 
preferences. Also, as alluded to throughout, future studies should more explicitly consider the directionality of policy proposals beyond issue ownership. While ownership provides a baseline for exploring these connections, explicitly measuring the directionality of the bill would provide a more stringent test of the degrees to which legislators respond to constituents.

As such, this research provides a step in understanding of both bill sponsorship, as well as the impacts of constituents on their elected officials, while taking a different step in distinguishing sponsorship from roll call voting. Still, many questions remain ripe for further inquiry on both of these fronts. For example, what are the institutional and contextual factors conditioning legislative responsiveness? What is the role of salience in issue ownership? Answers to these and other questions are important for studies on responsiveness, representation, and legislative behavior.

Editor's Note: Supplementary material follows the bibliography below. 


\section{References}

Aaron, Henry J., and Kevin Lucida. "Health Insurance Exchanges Fulfill Both Liberal and Conservative Goals.” Brookings Institution, October 1, 2013. https://www.brookings.edu/ opinions/health-insurance-exchanges-fulfill-both-liberal-and- conservative-goals/ (accessed September 29, 2016).

Abramowitz, Alan I., and Kyle L. Saunders. 2008. "Is Polarization a Myth?” Journal of Politics, $70(2): 542-555$.

Achen, Christopher H. 1978. “Measuring Representation.” American Journal of Political Science, 22(3): 475-510.

Adler, E. Scott, and John S. Lapinski. 1997. "Demand-Side Theory and Congressional Committee Composition: A Constituency Characteristics Approach.” American Journal of Political Science, 41(3): 895-918.

Adler, E. Scott, and John D. Wilkerson. 2012. Congress and the Politics of Problem Solving. New York: Cambridge University Press.

Alexander, Dan, Christopher R. Berry, and William G. Howell. 2016. "Distributive Politics and Legislator Ideology.” Journal of Politics, 78(1): 214-231.

Anderson, William D, Janet M Box-Steffensmeier and Valeria Sinclair-Chapman. 2003. "The keys to legislative success in the US House of Representatives." Legislative Studies Quarterly 28(3):357- 386.

Ashworth, Scott, and Ethan Bueno de Mesquita. 2006. "Delivering the goods: Legislative particularism in different electoral and institutional settings." Journal of Politics 68(1): 168-179.

Bafumi, Joseph, and Michael C. Herron. 2010. "Leapfrog Representation and Extremism: A Study of American Voters and Their Members in Congress." American Political Science Review, 104(3): 519-542.

Bafumi, Joseph, and Robert Y. Shapiro. 2009. “A New Partisan Voter.” Journal of Politics, 71(1): $1-24$.

Barnello, Michelle A., and Kathleen A. Bratton. 2007. "Bridging the Gender Gap in Bill Sponsorship." Legislative Studies Quarterly, 32(3): 449-474.

Baumgartner, Frank R., and Bryan D. Jones. 1993. Agendas and Instability in American Politics. Chicago: University of Chicago Press.

Bianco, William T. 1994. Trust: Representatives and Constituents. Ann Arbor: University of Michigan Press. 
Bishin, Benjamin G. 2009. Tyranny of the Minority: The Subconstituency Politics Theory of Representation. Philadelphia: Temple University Press.

Burnstein, Paul, Shawn Bauldry, and Paul Froese. 2005. "Bill Sponsorship and Congressional Support for Policy Proposals, from Introduction to Enactment or Disappearance." Political Research Quarterly, 58(2): 295-302.

Cameron, Charles, David Epstein, and Sharyn O’Halloran. 1996. "Do Majority-Minority Districts Maximize Substantive Black Representation in Congress?” American Political Science Review, 90(4): 794-812.

Carey, John M. 2007. “Competing Principals, Political Institutions, and Party Unity in Legislative Voting.” American Journal of Political Science, 51(1): 92-107.

Cayton, Adam F. 2016. "Consistency versus Responsiveness: Do Members of Congress Change Positions on Specific Issues in Response to Their Districts?” Political Research Quarterly, (September 2016): 1-16.

Clinton, Joshua D. 2006. "Representation in Congress: Constituents and Roll Calls in the 106th House." Journal of Politics, 68(2): 397-409.

Cox, Gary and Mathew D. McCubbins. 2005. Setting the Agenda. New York: Cambridge University Press.

Davis, Darren W., and Brian D. Silver. 2004. "Civil Liberties vs. Security: Public Opinion in the Context of the Terrorist Attacks on America." American Journal of Political Science, 48(1): $28-46$.

Egan, Patrick J. 2013. Partisan Priorities: How Issue Ownership Drives and Distorts American Politics. New York: Cambridge University Press.

Erikson, Robert S., Michael B. Mackuen, and James A. Stimson. 2002. The Macro Polity. New York: Cambridge University Press.

Erikson, Robert S., Gerald C. Wright, and John P. McIver. 1993. Statehouse Democracy: Public Opinion and Policy in the American States. Cambridge: Cambridge University Press.

Eulau, Heinz, and Paul D. Karps. 1977. “The Puzzle of Representation: Specifying Components of Responsiveness.” Legislative Studies Quarterly, 2(3): 233-254.

Evans, C. Lawrence. 1991. Leadership in committee. Ann Arbor: University of Michigan Press.

Fenno, Richard. 1978. Home style. Boston: Little Brown Publishers.

Finocchiaro, Charles J., David W. Rohde. 2008. "War for the floor: Partisan theory and agenda control in the U.S. House of Representatives.” Legislative Studies Quarterly, 33(1): 35-61. 
Fowler, Anthony, and Andrew B. Hall. 2012. "Conservative Vote Probabilities: An Easier Method for the Analysis of Roll Call Data." Unpublished manuscript.

Fowler, Anthony, and Andrew B. Hall. 2016. “The Elusive Quest for Convergence.” Quarterly Journal of Political Science, 11:131-149.

Gamm, Gerald, and Thad Kousser. 2010. "Broad bills or particularistic policy? Historical patterns in American state legislatures." American Political Science Review 104(1): 151-170.

Gerber, Elisabeth R. 1996. "Legislative Response to the Threat of Popular Initiatives." American Journal of Political Science, 40(1): 99-128.

Gilens, Martin. 2005. "Inequality and Democratic Responsiveness." Public Opinion Quarterly, 69(5): 778-796.

Griffin, John D., and Patrick Flavin. 2011. "How Citizens and Their Legislators Prioritize Spheres of Representation.” Political Research Quarterly, 64(3): 520-533.

Grimmer, Justin. 2013a. Representational Style in Congress: What Legislators Say and Why It Matters. New York: Cambridge University Press.

Grimmer, Justin. 2013b. “Appropriators not Position Takers: The Distorting Effects of Electoral Incentives on Congressional Representation." American Journal of Political Science, 57(3): 624-642.

Grose, Christian R., Neil Malhotra, and Robert Parks Van Houweling. 2015. "Explaining Explanations: How Legislators Explain their Policy Positions and How Citizens React." American Journal of Political Science, 59(3): 724-743.

Hall, Richard L and C. Lawrence Evans. 1990. “The power of subcommittees.” Journal of Politics, 52(2):335-355.

Hall, Richard L., and Frank W. Wayman. 1990. "Buying time: Moneyed interests and the mobilization of bias in congressional committees." American political science review 84(3): 797-820.

Harden, Jeffrey J. 2013. “Multidimensional Responsiveness: The Determinants of Legislators' Representational Priorities.” Legislative Studies Quarterly, 38(2): 155-184.

Harden, Jeffrey J. 2016. Multidimensional Democracy: A Supply and Demand Theory of Representation in American Legislatures. New York: Cambridge University Press.

Henderson, Michael B. 2015. "How Far Apart Are Democrats and Republicans on School Reform?” Brookings Institution, Brown Center Chalkboard. 
Henderson, Michael B., Paul E. Peterson, and Martin R. West. 2014. "Program on Education Policy and Governance: Survey 2014.” Education Next, http://educationnext.org/files/ 2014ednextpoll.pdf (accessed September 29, 2016).

Hetherington, Marc J., and Thomas J. Rudolph. 2015. Why Washington Won't Work: Polarization, Political Trust, and the Governing Crisis. Chicago: University of Chicago Press.

Jones, Jeffrey M. "Democrats More Liberal on Social Issues Than Economic Ones." Gallup, May 20, 2016. http://www.gallup.com/poll/191741/democrats-liberal-social-issues-economicones.aspx (accessed September 29, 2016).

Kiewiet, D. Roderick, and Michael Udell. 1998. “Twenty-Five Years after Kramer: An Assessment of Economic Retrospective Voting based upon Improved Estimates of Income and Unemployment." Economics \& Politics, 10(3):219-248.

Lawrence, Eric D, Forrest Maltzman and Steven S Smith. 2006. "Who wins? Party effects in legislative voting." Legislative Studies Quarterly, 31(1):33-69.

Lax, Jeffrey, and Justin Phillips. 2009a. "Gay Rights in the States: Public Opinion and Policy Responsiveness.” American Political Science Review, 103 (3): 367-86.

Lax, Jeffrey, and Justin Phillips. 2009b. "How Should We Estimate Public Opinion in the States?” American Journal of Political Science, 53(1): 107-121.

Lax, Jeffrey, and Justin Phillips. 2012. “The Democratic Deficit in the States.” American Journal of Political Science, 56(1): 148-166.

Levendusky, Matthew. 2009. The Partisan Sort: How Liberals Became Democrats and Conservatives Became Republicans. Chicago: University of Chicago Press.

Levendusky, Matthew. 2010. “Clearer Cues, More Consistent Voters: A Benefit of Elite Polarization.” Political Behavior, 32(1): 111-131.

Lewis-Beck, Michael S., and Mary Stegmaier. 2000. "Economic Determinants of Electoral Outcomes.” Annual Review of Political Science, 3(1): 183-219.

Mayhew, David. 1974. Congress: The Electoral Connection. New Haven: Yale University Press.

McCarthy, Justin. “Americans Split on Defense Spending.” Gallup, February 20, 2015. http:// www.gallup.com/poll/181628/americans-split-defense-spending.aspx (accessed September 29, 2016).

Miller, Warren E., and Donald E. Stokes. 1963. "Constituency Influence in Congress.” American Political Science Review, 57(1): 45-56. 
Newport, Frank. 2013. "Democrats, Republicans See Many U.S. Industries Differently." Gallup, August 23, 2013. http://www.gallup.com/poll/164111/democrats-republicans-industriesdifferently.aspx (accessed November 10, 2016).

Page, Benjamin I., and Robert Y. Shapiro. 1992. The Rational Public: Fifty Years of Trends in Americans' Policy Preferences. Chicago: University of Chicago Press.

Page, Benjamin I., Robert Y. Shapiro, Paul W. Gronke, and Robert M. Rosenberg. 1984. "Constituency, Party, and Representation in Congress." Public Opinion Quarterly, 48(4): 741-756.

Peress, Michael. 2013. "Candidate Positioning and Responsiveness to Constituent Opinion in the U.S. House of Representatives.” Public Choice, 156(1): 77-94.

Petrocik, John R. 1996. “Issue Ownership in Presidential Elections, with a 1980 Case Study." American Journal of Political Science, 40(3): 825-850.

Pew Research Center. "Section 3: Political Polarization and Personal Life." Pew Research Center: U.S. Politics Policy, June 12, 2014. http://www.people-press.org/ 2014/06/12/ section-3-political-polarization-and-personal-life/ (accessed September 29, 2016).

Poole, Keith T., and Howard Rosenthal. 1997. Congress: A Political-Economic History of Roll Call Voting. Oxford: Oxford University Press.

Rocca, Michael S., and Stacy B. Gordon. 2010. “The Position-Taking Value of Bill Sponsorship in Congress.” Political Research Quarterly, 63(2): 387-397.

Rocca, Michael S., and Gabriel R. Sanchez. 2008. "The Effect of Race and Ethnicity on Bill Sponsorship and Cosponsorship in Congress.” American Politics Research, 36(1): 130.

Schiller, Wendy J. 1995. “Senators as Political Entrepreneurs: Using Bill Sponsorship to Shape Legislative Agendas.” American Journal of Political Science, 39(1): 186-203.

Shapiro, Robert Y. 2011. "Public Opinion and American Democracy." Public Opinion Quarterly, 75(5): 982-1017.

Shipan, Charles R. and William R. Lowry. 2001. "Environmental Policy and Party Divergence in Congress." Political Research Quarterly, 54(2): 245-263.

Squire, Peverill, and Keith E. Hamm. 2005. 101 Chambers: Congress, State Legislatures and the Future of Legislative Studies. Columbus: Ohio State University Press.

Stimson, James A., Michael B. Mackuen, and Robert S. Erikson. 1995. "Dynamic

Representation.” American Political Science Review, 89 (3): 543-65. 
Tausanovitch, Chris, and Christopher Warshaw. 2013."Measuring Constituent Policy

Preferences in Congress, State Legislatures, and Cities." Journal of Politics, 75 (2): 330-342.

Volden, Craig, and Alan E. Wiseman. 2014. Legislative Effectiveness in the United States Congress: The Lawmakers. New York: Cambridge University Press.

Waggoner, Philip D. 2018. "Do Constituents Influence Issue-Specific Bill Sponsorship?” American Politics Research, doi: 1532673X18759644.

Wawro, Gregory. 2001. Legislative entrepreneurship in the US House of Representatives. Ann Arbor: University of Michigan Press.

Whitby, Kenny J. 2002. "Bill Sponsorship and Intraracial Voting among African American Representatives." American Politics Research, 30(1): 93-109.

Wilson, Walter Clark. 2010. "Descriptive Representation and Latino Interest Bill Sponsor-ship in Congress.” Social Science Quarterly, 91(4): 1043-1062.

Woon, Jonathan. 2008. "Bill Sponsorship in Congress: The Moderating Effect of Agenda Positions on Legislative Proposals.” Journal of Politics, 70(1): 201-216.

Woon, Jonathan. 2009. “Issue Attention and Legislative Proposals in the US Senate." Legislative Studies Quarterly, 34(1): 29-54. 


\section{Supplementary Material}



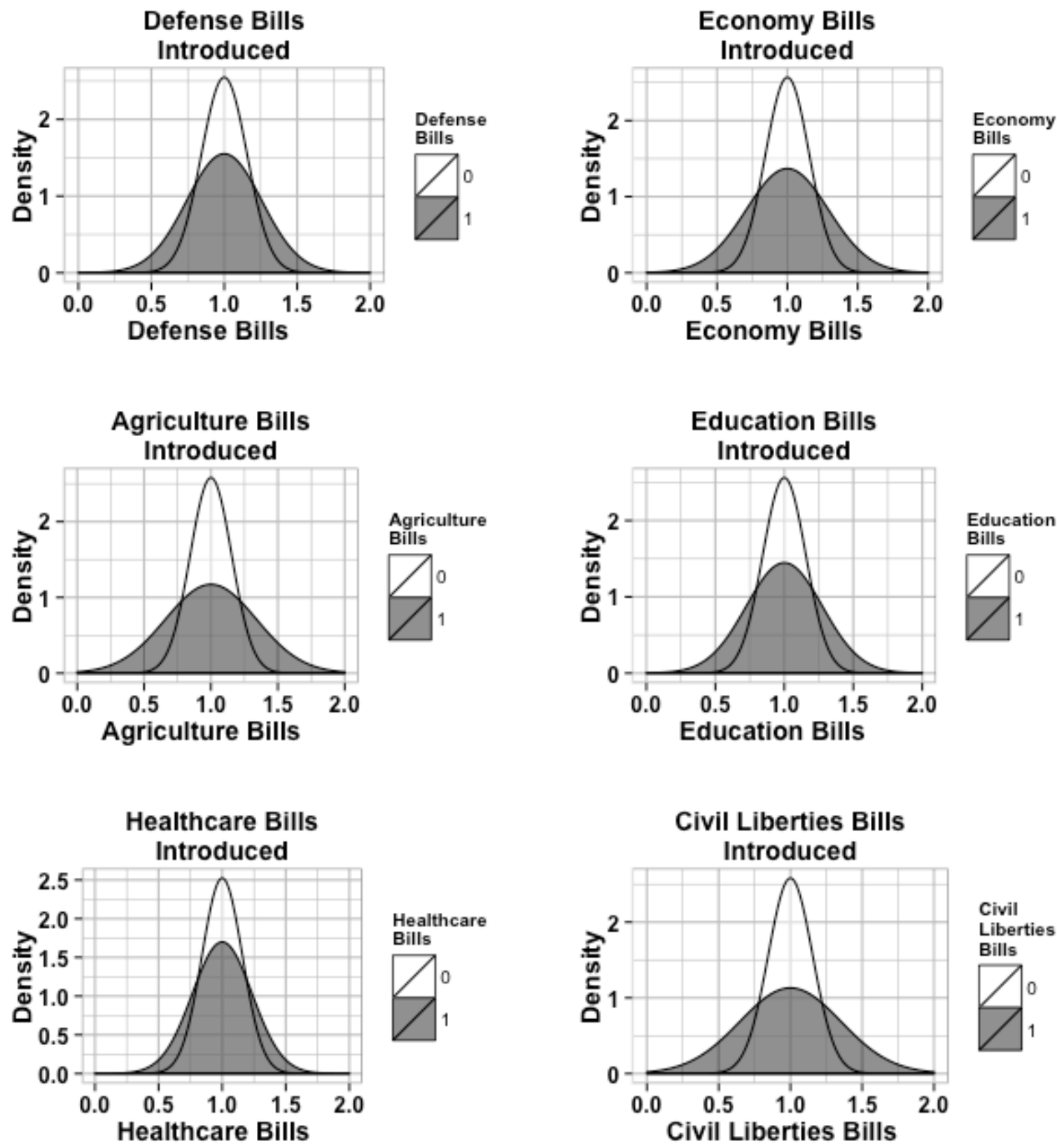

Figure A1: Density of Sponsored Bills by Issue 


\begin{tabular}{|l|l|l|l|l|l|l|l|l|l|}
\hline \multicolumn{10}{|c|}{ Table A1: Variance Inflation Factor (VIF) For Each Model } \\
\hline Model & $\begin{array}{l}\text { Const. } \\
\text { Ideol. }\end{array}$ & $\begin{array}{l}\text { DW- } \\
\text { NOM }\end{array}$ & Maj. & Sen. & LES & $\begin{array}{l}\text { Power } \\
\text { Comm. }\end{array}$ & $\begin{array}{l}\text { Subcom. } \\
\text { Chair }\end{array}$ & Party & $\begin{array}{l}\text { District } \\
\text { Char. }\end{array}$ \\
\hline Defense & 1.6434 & 2.1638 & 1.4214 & 1.3923 & 1.5104 & 1.0777 & 1.2835 & 2.4823 & 1.0490 \\
\hline Economy & 1.7627 & 2.1113 & 1.3513 & 1.4735 & 1.5701 & 1.1329 & 1.2393 & 2.6997 & 1.0896 \\
\hline Agricul. & 1.7561 & 2.0758 & 1.4084 & 1.3497 & 1.4113 & 1.1042 & 1.2957 & 2.4019 & 1.2028 \\
\hline Educ. & 1.6843 & 2.1044 & 1.4269 & 1.4003 & 1.4837 & 1.0760 & 1.2986 & 2.4740 & 1.0477 \\
\hline Health & 1.7031 & 2.1159 & 1.4205 & 1.3412 & 1.4019 & 1.0735 & 1.3008 & 2.5734 & 1.0510 \\
\hline CL/CR & 2.0704 & 2.2030 & 1.5352 & 1.3446 & 1.4872 & 1.0398 & 1.3904 & 2.7258 & 1.2959 \\
\hline
\end{tabular}

Checking for multicollinearity in every model using the standard variance inflation factor (VIF) statistic,

$$
V I F_{j}=\frac{1}{1-R_{j}^{2}}
$$

where $R_{j}^{2}$, is the coefficient of determination obtained by regressing each X on all other $X^{\prime}$ 's in the model. A VIF value $\geq 10$, suggests the given variable is a problem, meaning it is highly collinear with another variable in the model, thereby threatening output and inferences. Note than no VIF values in Table A1 approach 10, suggesting that while indeed party and ideology likely correlate, for example, it is not problematic to keep each covariate in the models. 